\section{JCLIC CONTINUES}

The Junior College Library Information Center at American Library Association headquarters is being continued for an additional three-month period through May 31. The Center was established by a grant of $\$ 15,000$ from the 1967-68 J. Morris Jones-World Book Encyclopedia-ALA Goals Award and has served to collect and to make available informative materials about junior college libraries and library programs. The Center is under the direction of Peggy Sullivan on a half-time basis.

Many of the materials forwarded to the Center from two-year college librarians and others interested in its development have been incorporated in the Headquarters Library of the American Library Association. These include staff handbooks, faculty handbooks, student handbooks, materials on two-year college library buildings, etc. Materials retained in the Junior College Library Information Center include blueprints and plans for two-year libraries, materials that are available on request, and materials which may be consulted by visiting the Center. Copies of annual reports, budgets, project proposals (whether funded or not), newsletters, handbooks, and other items which may be especially helpful to those starting or developing two-year college library programs are especially solicited for the Center's collection. When the Center is discontinued May 31 these materials will be made available through other agencies of the American Library Association or outside agencies which have means for using them or distributing them to interested persons.

\section{ASSISTANCE FOR LIBRARY EDUCATION}

A new publication listing scholarships and other financial assistance available for the academic year 1969-70 to students entering the profession of librarianship has just been announced by the Library Education Division of the American Library Association.

The guide for parents, counselors, and students alike, Financial Assistance for $\mathrm{Li}_{\text {- }}$ brary Education is available through the Office for Recruitment of ALA, 50 East Huron Street, Chicago, Illinois 60611.

The publication provides a list of scholarships and grants administered through state library agencies, national and state library associations and associations of school librarians, ALA accredited library schools, and other institutions offering graduate or undergraduate programs in library education. National associations, foundations and other agencies known to grant financial assistance for library education are also listed.

Members of the LED committee on revision of the pamphlet are Helen B. Schmidt, chairman; Margaret J. Byergo; Dorothy L. Cromien; Eliza A. Gleason; and Elinor Yungmeyer.

Copies of the publication are available at the following prices: one copy, 50 cents; 10 copies, $\$ 4.75 ; 25$ copies, $\$ 11.25$; and 100 copies, $\$ 42.00$.

\section{INDIANA UNIVERSITY LIBRARY SUFFERS FIRE LOSS}

A fire of undetermined origins in the main library building at Indiana University on February 17 caused an estimated $\$ 500,000$ damage to library collections. A complete count of book losses has not yet been made. It is known, however, that 3811 volumes of domestic and foreign newspapers and several hundred reference works were totally destroyed. Library authorities estimate that more than $30,000 \mathrm{vol}$ umes damaged by heat, smoke or water must be either rebound or replaced. Building damage has not been estimated. The building and its contents were insured.

Three floors in the sixty-two year old main library building were damaged. The fire originated in a sub-basement area used for newspaper storage and spread through ventilating ducts to the basement above and the main reference room on the first floor. Bloomington firemen brought the blaze under control within four hours after arriving on the scene.

The destroyed newspapers consisted of fortyfour different titles, including The Times (London), Manchester Guardian, Illustrated London News, San Francisco Examiner, St. Louis Post. Dispatch, Chicago Journal of Commerce, the Wall Street Journal and other domestic and foreign dailies and weeklies. Reference works destroyed included dictionaries, encyclopedias, indexes and abstracts. Monographs destroyed or damaged related to Near Eastern Studies, German and French literature, geography, political science, and international law and organization. Immediate steps have been taken to replace the newspapers with microfilm copies where available. All in-print titles destroyed will be replaced. Emergency binding shipments are being sent weekly to a commercial binder to replace the damaged bindings. The fire occurred approximately two months before all books in the old building were scheduled to be moved into a new $\$ 14,000,000$ library building nearing completion. 